\title{
Assessing the instability of Dong Nai River in Bien Hoa District using Bank Erosion Hazard Index (BEHI) and Remote Sensing and GIS
}

\author{
Lan, P.T.H. ${ }^{\text {a, }}$ Nguyet, L.M. ${ }^{\text {a }}$,Hoa, L.T.V. ${ }^{b}$ \\ ${ }^{a}$ Thuy loi University (Water Resourses University), lanpth@wru.vn; nguyetlm410@wru.vn \\ ${ }^{b}$ Department of Water Resources Management - Ministry of Natural Resources and Environment: flower.hoa@gmail.com
}

\begin{abstract}
In this study, a method for developing a quantitative prediction of river bank erosion in Bien Hoa district in Dong Nai River is presented. The river bank erosion hazard index (BEHI) was estimated to assess the stability of the river bank erosion in consultation with bank height, bank slope, rooting depth, rooting density and surface protection. The estimated BEHI of Dong Nai River in Bien Hoa district are high which indicates the riverbank instability. The estimated BEHI along the left bank is about 25-30. The satellite data of LANSAT TM 5, LANDSAT ETM 7 for the year 1995, 2005 and 2015 were used to assess the nature of shifting of the river bank and to estimate the land loss from river bank. All the derived images were transported on GIS environment to extract the course of the river. 13 sites were considered along the Dong Nai River in Bien Hoa District to estimate the leftward shifting of the bank line and to assess the shifting distance of the river bank line. There is a strong relationship between bank instability BEHI, shifting distance of the bank line and eroded bank area in this study.
\end{abstract}

Keywords: Bank erosion, Dong Nai River, BEHI, bank instability, GIS

\section{Introduction}

Riverbank erosion is one of the most severe phenomenon in the rural area of Vietnam, including Dong Nai province. Once an erosion occurs, the natural disaster has a negative impact on people's life and community's activity. There are many methods of assessing riverbank erosion, one of which is the method of using the Bank Erosion Hazard Index. Stream bank assessment includes the measurements of bank heights, angles, materials, presence of layers, rooting depth, rooting density and percentage of bank protection which are used to develop the Bank Erosion Hazard Index (BEHI). BEHI was estimated after Rosgen (2001a and 2001b) to assess the nature of credibility of the river bank in Manikchak. The BEHI methodology evaluates a stream bank's susceptibility to erosion as a function of five factors, including:

1. The ratio of stream bank height to bank full stage.

2. The ratio of riparian vegetation rooting depth to stream bank height.

3. The degree of rooting density.

4. Stream bank angle (i.e., slope)

5. Bank surface protection afforded by debris and vegetation.

The changes in the flow character as a result of siltation and sedimentation as well as variation in discharge invited severe river bank erosion in Bienhoa of Dong Nai. The present study is dealt with the study of river bank erodibility based on BEHI as well as nature and extent of the bank line shifting leftward with the help of RS \& GIS which revealed the impact of the fluvial dynamics of river Dong Nai on bank erosion hazards in the concern area.

\section{Study Area}

Bien Hoa City is located in the west of Dong Nai province, borders Vinh Cuu district in the north, Long Thanh district in the south, Trang Bom district in the east, Di An town, Tan Uyen district of Binh Duong province and District 9 of Ho Chi Minh in the west. Bien Hoa City has a total area of about 263,55 km2 (Figure 1).

The Dong Nai River runs through Bien Hoa City with a length of $21 \mathrm{~km}$ and plays an important role in the development of Bien Hoa City, Dong Nai Province in particular and the Southern Key Economic Zone in general. Crossing the river is the North-South railway (through Ghenh bridge and Rach Cat bridge), National Highway 1A (Dong Nai bridge), Hoa An bridge. Along the banks of the river are provincial agencies, residential areas, commercial areas, factories, industrial parks, wharves, etc. of Ho Chi Minh City.

The morphological characteristics of the Dong Nai river in the river section through Bien Hoa city are shown in the following table: 


\begin{tabular}{|c|c|c|c|c|c|c|c|}
\hline \multirow{2}{*}{ No. } & \multirow{2}{*}{ The River } & \multirow{2}{*}{$\begin{array}{l}\text { Length } \\
\mathrm{L}(\mathrm{m})\end{array}$} & \multicolumn{3}{|c|}{ River width (m) } & \multirow{2}{*}{$\begin{array}{l}\text { Level } Z(\mathrm{~m}) \\
\text { lowest bottom } \\
\mathrm{Z}_{\text {min }}\end{array}$} & \multirow{2}{*}{$\frac{\sqrt{B}}{h}$} \\
\hline & & & $\mathrm{B}_{\max }$ & $\mathrm{B}_{\min }$ & $\mathrm{B}_{\text {avarage }}$ & & \\
\hline 1 & Isle of Tortoise to Hoa An bridge & 4200 & 750 & 210 & 600 & $-15.29 \div-16.24$ & $2.23 \div 3.99$ \\
\hline 2 & Hoa An Bridge to $\mathrm{Cu}$ Lao Pho & 2800 & 810 & 450 & 620 & $-17.32 \div-18.62$ & $1.40 \div 4.01$ \\
\hline 3 & $\mathrm{Cu}$ Lao Pho to Dong Nai Bridge & 950 & 580 & 330 & 515 & $-15.57 \div-19.76$ & $1.46 \div 2.11$ \\
\hline 4 & Dong Nai Bridge to Ba Xê, Ba Sang & 1450 & 680 & 330 & 460 & $-13.02 \div-13.69$ & $1.68 \div 2.94$ \\
\hline 5 & Rach Cat river & 7937 & 390 & 110 & 180 & $-8.09 \div-8.79$ & $2.16 \div 2.72$ \\
\hline 6 & The main river Dong Nai & 3100 & 420 & 275 & 378 & $-15.11 \div-15.95$ & $1.43 \div 1.92$ \\
\hline
\end{tabular}

Table 1. Morphological characteristics of Dong Nai River through Bien Hoa City.

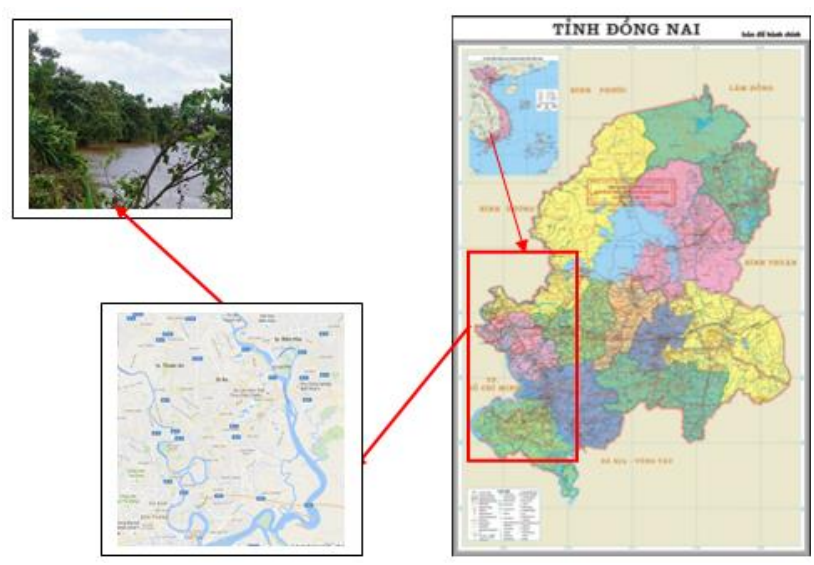

Figure 1. Location of bank erosion in Bien Hoa - Dong Nai.

River morphology of the Dong Nai river section flowing through Bien Hoa city falls into the category of the slightly curved river and creeks division. River-bed morphology demonstrates the characteristics of intertidal rivers, semidiurnal regime of the East Sea, and the flow regulating effect of Tri An reservoir in the upstream.

In the river bed formed many local erosion holes (06 erosions with bottom elevation $\mathrm{Zmin}>-10 \mathrm{~m}$ ). The erosion formed into the confluence zone with $\mathrm{Zmin}=-19.76 \mathrm{~m}$, the curve's tip $\mathrm{Zmin}=-20.14 \mathrm{~m}$, the contraction zone $\mathrm{Zmin}=$ $-20.56 \mathrm{~m}$.

The Dong Nai River section in Bien Hoa City forms creek division, this formation stems from water flow, sediment flow and riverbank geology with low ability to resist erosion, river-bed expanding and narrowing along the river (narrowing's effect is to control river's morphology) where sediment flow divided, and the expanding section where more sediment depositing.

Under cutting or loss of underlying support is the primary cause of bank erosion at Dong Nai River. As a result of hydraulic action, the soil particles of underlying layer is detached and carried far away by stream flow which results in overhanging layer at the top. This overhanging layer with time collapse and execute rapid bank erosion.

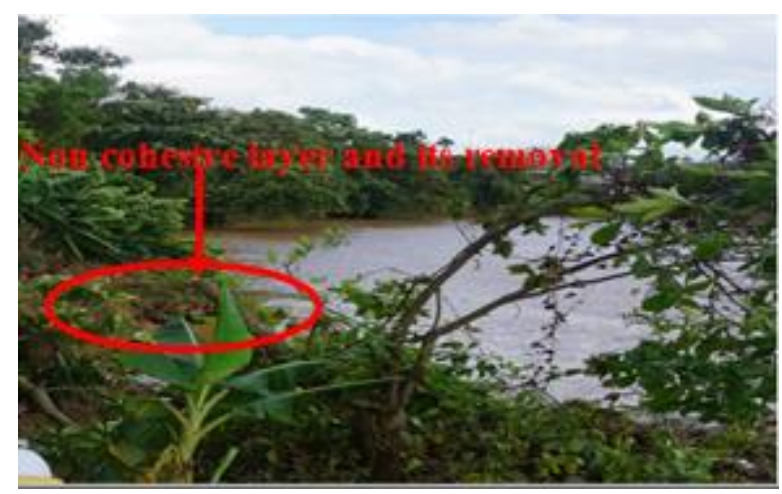

Figure 2. Cohesive and non-cohesive layers at Dong Nai River

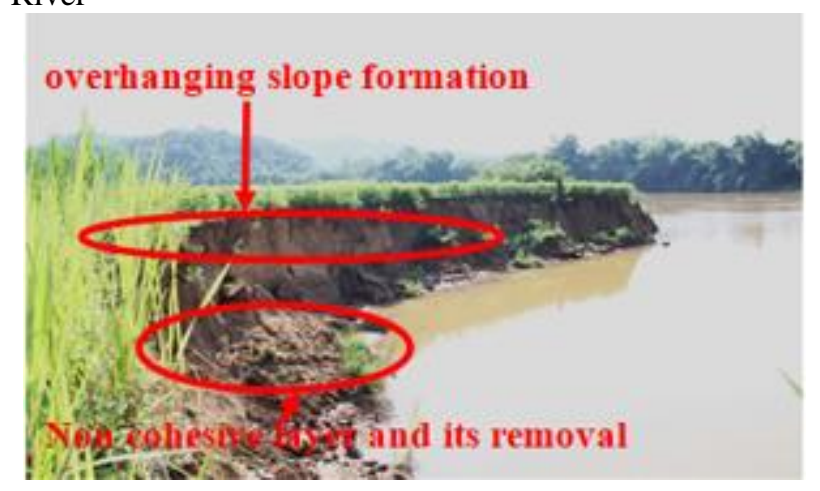

Figure 3. Cohesive and non-cohesive layers at Dong Nai River

This study is an attempt to examine the spatial bank erosion condition of Dong Nai River in Bien Hoa City. The study focus on the nature and extent of riverbank erosion of Dong Nai River, estimation of the ratio of stream bank height to bank full stage, ratio of riparian vegetation rooting depth to stream bank height, rooting density, riverbank angle and surface protection, the assessment of the bank erosion hazard index (BHEI) and to assess the potential erosion sites in the Dong Nai River.

\section{Materials and methods}

\subsection{Estimation of Bank Erosion Hazard Index (BEHI)}

The River bank with various BEHI parameters as following figure: 


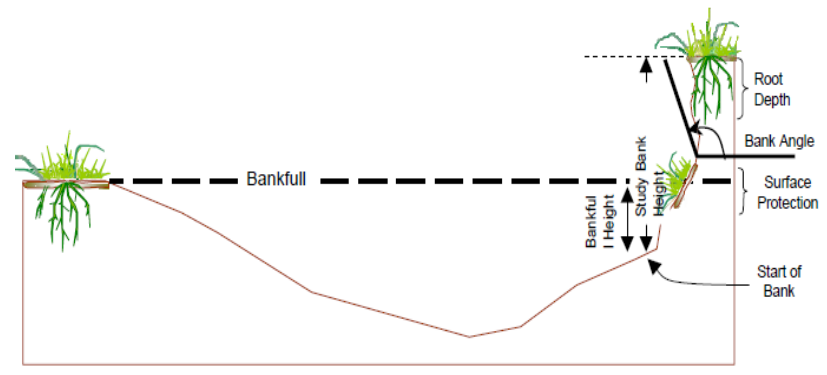

Figure 4. River bank with various BEHI parameters.

Rosgen (2001) calculated this index by summing the scores for each individual metric using the values assigned for measuring complete BEHI as following:

\begin{tabular}{|c|c|c|c|c|c|c|c|c|c|c|}
\hline $\begin{array}{l}\text { BEHI } \\
\text { Category }\end{array}$ & $\begin{array}{l}\text { Bank } \\
\text { Height / } \\
\text { Bankfull } \\
\text { Height }\end{array}$ & $\begin{array}{l}\text { BH/BFH } \\
\text { Score }\end{array}$ & $\begin{array}{l}\text { Root } \\
\text { Depth } \\
\text { (\% of } \\
\text { BFH) }\end{array}$ & $\begin{array}{l}\text { Root } \\
\text { Depth } \\
\text { Score }\end{array}$ & $\begin{array}{l}\text { Root } \\
\text { Density } \\
(\%)\end{array}$ & $\begin{array}{l}\text { Surface } \\
\text { Protection } \\
\text { (Avg. \%) }\end{array}$ & $\begin{array}{l}\text { Surface } \\
\text { Protection } \\
\text { Score }\end{array}$ & $\begin{array}{l}\text { Bank } \\
\text { Angle } \\
\text { (degrees) }\end{array}$ & $\begin{array}{l}\text { Bank } \\
\text { Angle } \\
\text { Score }\end{array}$ & $\begin{array}{l}\text { Total } \\
\text { Score, } \\
\text { by } \\
\text { Category }\end{array}$ \\
\hline Very low & $1.0-1.1$ & 1.45 & $\begin{array}{l}90- \\
100\end{array}$ & 1.45 & $80-100$ & 80-100 & 1.45 & $0-20$ & 1.45 & $\begin{array}{l}\leq 7.25 \\
7.26-\end{array}$ \\
\hline Low & $1.11-1.19$ & 2.95 & $50-89$ & 2.95 & $55-79$ & $55-79$ & 2.95 & $21-60$ & 2.95 & $\begin{array}{l}14.75 \\
14.76-\end{array}$ \\
\hline Moderate & $1.2-1.5$ & 4.95 & $30-49$ & 4.95 & $30-54$ & $30-54$ & 4.95 & $61-80$ & 4.95 & 24.75 \\
\hline High & $1.6-2.0$ & 6.95 & $15-29$ & 6.95 & $15-29$ & $15-29$ & 6.95 & $81-90$ & 6.95 & 24.76- \\
\hline Very & & & & & & & & & & 34.76- \\
\hline high & $2.1-2.8$ & 8.5 & $5-14$ & 8.5 & $5-14$ & $10-14$ & 8.5 & $91-119$ & 8.5 & 42.50 \\
\hline Extreme & $>2.8$ & 10 & $<5$ & 10 & $<5$ & $<10$ & 10 & $>119$ & 10 & $42.51-50$ \\
\hline
\end{tabular}

Table 2. Guidelines for measuring complete BEHI (After, Rosgen, 2001).

\subsection{Estimation of the Shifting of the river bank leftward}

Landsat images for the year 1988 - 2016 were used in ERDAS IMAGINE PC software (9.2) using WGS 84 projection system which was inbuilt in the Landsat data where root mean square error was approximately 0.982 and, an acceptable limit (Pham Thi Huong Lan, 2017). All data was integrated in a GIS environment to understand the controls and mechanism of river dynamics as following:

\begin{tabular}{|c|c|c|c|c|c|}
\hline \multirow{2}{*}{ No. } & \multicolumn{2}{|c|}{ Dry season } & \multicolumn{2}{|c|}{ Flood season } & \multirow{2}{*}{ Data Type } \\
\hline & Details & Year/ Date & Details & Year/ Date & \\
\hline 1 & $125-025$ & $12 / 3 / 1988$ & $125-025$ & $27 / 09 / 1988$ & Landsat TM \\
\hline 2 & $125-025$ & $4 / 2 / 1990$ & $125-025$ & $13 / 10 / 1990$ & Landsat TM \\
\hline 3 & $125-025$ & $2 / 2 / 1995$ & $125-025$ & 9/10/1995 & Landsat TM \\
\hline 4 & $125-025$ & 21/02/1999 & $125-025$ & $6 / 10 / 1999$ & Landsat ETM \\
\hline 5 & $125-025$ & $25 / 02 / 2000$ & $125-025$ & $12 / 10 / 2000$ & Landsat 7 ETM \\
\hline 6 & $125-025$ & $13 / 02 / 2002$ & $125-025$ & $15 / 10 / 2002$ & Landsat 7 ETM \\
\hline 7 & $125-025$ & $27 / 02 / 2003$ & $125-025$ & $11 / 10 / 2003$ & Landsat 7 ETM \\
\hline 8 & $125-025$ & $3 / 2 / 2008$ & $125-025$ & $12 / 10 / 2008$ & Landsat 7 ETM \\
\hline 9 & $125-025$ & $21 / 02 / 2014$ & $125-025$ & $18 / 09 / 2014$ & Landsat 8 ETM \\
\hline 10 & $125-025$ & $9 / 2 / 2015$ & $125-025$ & $12 / 10 / 2015$ & Landsat 8 ETM \\
\hline 11 & $125-025$ & $31 / 03 / 2016$ & $125-025$ & $19 / 08 / 2016$ & Landsat 8 ETM \\
\hline
\end{tabular}

Table 3. Specification of the satellite Data. 


\section{Results and Discussion}

\subsection{Estimated BEHI and Instability of the river bank}

In this study, the authors used primary collected data from 2008, 2015 and 2016. Site's specific information was derived after four-day intensive field investigation in October 2016 with GPS, Clinometer, and measuring tape, measuring staff and hanging rope.

The results of estimated BEHI from different location of Dong Nai River Bank is statistics in the table as following:

\begin{tabular}{|l|l|l|l|l|l|l|l|l|}
\hline Location & $\mathrm{X}$ & $\mathrm{Y}$ & $\begin{array}{l}\text { Study } \\
\text { Bank } \\
\text { Height } / \\
\text { Bankfull } \\
\text { Height }\end{array}$ & $\begin{array}{l}\text { Root } \\
\text { Depth/Bank } \\
\text { Height }\end{array}$ & $\begin{array}{l}\text { Root } \\
\text { Density } \\
(\%)\end{array}$ & $\begin{array}{l}\text { Surface } \\
\text { Protection } \\
(\%)\end{array}$ & $\begin{array}{l}\text { Bank } \\
\text { Angle }\end{array}$ & $\begin{array}{l}\text { Total } \\
\text { BEHI } \\
\text { Score }\end{array}$ \\
\hline MC1 & 396523.5 & $1,211,275.93$ & 2.3 & 9.2 & 20 & 50 & 75 & 34.9 \\
MC2 & 397926.3 & $1,210,490.61$ & 2.8 & 16.5 & 18 & 52 & 30 & 16.75 \\
MC3 & 398333.8 & 1210174.10 & 3.5 & 12.1 & 25 & 50 & 35 & 17.5 \\
MC4 & 398700.2 & 1209745.23 & 3.2 & 14.1 & 25 & 50 & 30 & 18.1 \\
MC5 & 398935.5 & 1209479.08 & 1.8 & 6.1 & 25 & 50 & 50 & 14.65 \\
MC6 & 399772.6 & 1210453.60 & 1.82 & 9.2 & 25 & 50 & 45 & 24.1 \\
MC7 & 401508.1 & 1210425.10 & 1.81 & 7.1 & 20 & 50 & 45 & 24.8 \\
MC8 & 401207.6 & 1209480.93 & 2.1 & 9.2 & 20 & 50 & 55 & 24.76 \\
MC9 & 400652.8 & 1207700.96 & 1.9 & 6.8 & 20 & 52 & 70 & 16.25 \\
MC10 & 398807.5 & 1208741.13 & 3.8 & 12.1 & 25 & 50 & 35 & 24.7 \\
MC11 & 399096.0 & 1208404.61 & 2.1 & 6.5 & 20 & 50 & 25 & 34.7 \\
MC12 & 399176.2 & 1207943.31 & 2.5 & 10.5 & 20 & 50 & 95 & 36.9 \\
MC13 & 399939.6 & 1207700.39 & 2.8 & 15.58 & 20 & 50 & 110 & 34.54 \\
\hline
\end{tabular}

Table 4. Estimated BEHI from different location of Dong Nai River Bank

Field survey took place at the location of Hoa An bridge at about 500m to the upstream of Dong Nai River (location MC1). A river cross profile was done along the left bank of Dong Nai River at Buu Long. The near bank river bed profile depicts that the depth is close to the river bank which plays a significant role to increase the velocity of water.

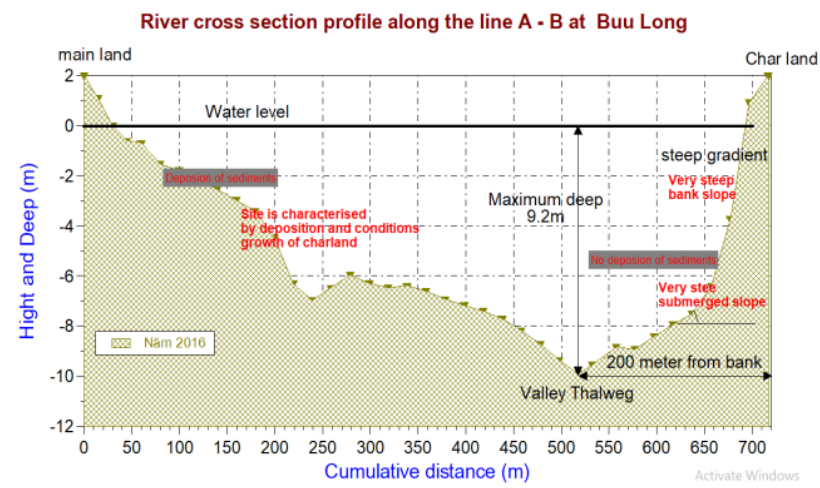

Figure 5. River cross profile between mainland and char land at Buu Long.

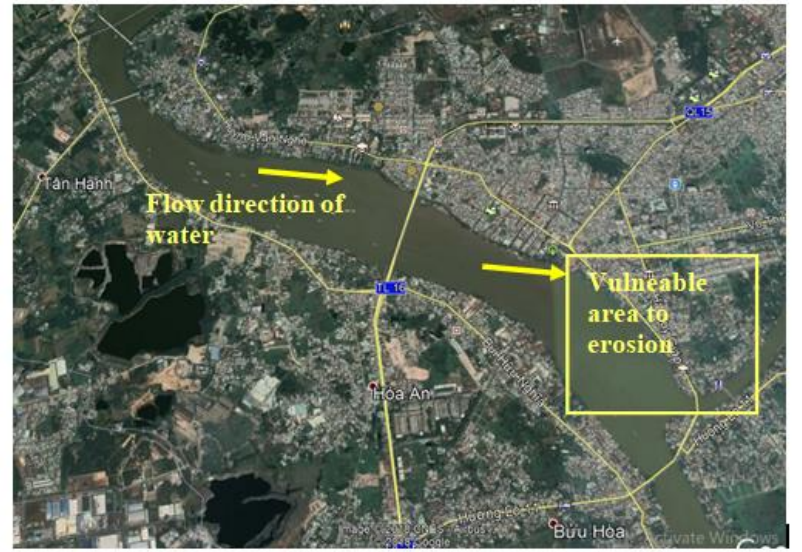

Figure 6: Vulnerable sites of bank erosion at Buu Long Bien Hoa.

\subsection{Shifting character of the bank of the Dong Nai river and estimated land loss}

Based on a map of river morphology, the authors assess, analyze, and finally identify a number of rules required for each specific area for forecasting, such as rate and scale of riverbank erosion, rate of sedimentation in riverbank, rate of erosion development in the islet area, rate of erosion hole development and movement, level of shallow according to space and time, etc.; estimate the scale and 
rate of riverbank erosion and erosion site in the project area from 1988 to 2016, as shown in the following table:

\begin{tabular}{|c|c|c|c|c|}
\hline Position & $\begin{array}{l}\text { River } \\
\text { bank }\end{array}$ & $\begin{array}{l}\text { Length of } \\
\text { landslide }(\mathrm{m})\end{array}$ & $\begin{array}{l}\text { The maximum } \\
\text { width of the } \\
\text { landslide }(\mathrm{m})\end{array}$ & $\begin{array}{l}\text { Average landslide rate } \\
\qquad(\mathrm{m} / \text { year })\end{array}$ \\
\hline Upstream of Hoa An bridge & Right & 820 & 10 & 0.32 \\
\hline $\begin{array}{l}\text { Lower section of Hoa An bridge } \\
\text { The } \mathrm{Cu} \text { Lao Pho area in the }\end{array}$ & Left & 700 & 30.5 & 1.2 \\
\hline downstream of Bien Hoa & Left & 192.5 & 17.7 & 0.63 \\
\hline $\begin{array}{l}\mathrm{Cu} \text { Lao Pho area } \\
\mathrm{Cu} \text { Lao Pho district (about } 550 \mathrm{~m} \\
\text { from the downstream of Ghenh }\end{array}$ & & 500 & 51.4 & 1.83 \\
\hline $\begin{array}{l}\text { bridge) } \\
\text { Cu Lao Pho (about 1200m }\end{array}$ & Right & 52 & 20 & 1.1 \\
\hline $\begin{array}{l}\text { downstream from Ghenh bridge) } \\
\text { Rach Cat river at the crest of Thong }\end{array}$ & Left & 70 & 17.8 & 0.63 \\
\hline $\begin{array}{l}\text { Nhat, Tan Mai, Tam Hiep } \\
\text { Unstream of Buu Hoa Bridge (about }\end{array}$ & Left & 1550 & 16.25 & 0.65 \\
\hline $100 \mathrm{~m})$ & Left & 128 & 16.27 & 0.58 \\
\hline Upstream of Dong Nai bridge & Left & 300 & 36.4 & 1.3 \\
\hline
\end{tabular}

Table 5. Shifting character of the river bank from 1988 to 2016.

\section{Conclusion}

Bank angle varies from $25^{\circ}$ to $110^{\circ}$. However, in most cases, the bank angle is $>70^{\circ}$, which leads to the increase of the BEHI score. Surface protection helps to reduce the BEHI score. The BEHI score ranges between 14.65 - 36.90 which is categorized into moderate (from 14.76 to 24.75 ), high (from 24.76 to 34.75 ) and very high (34.76 to 42.500 ) levels. Therefore, it clearly indicates that the sites' scale is characterized by river bank instability and erosion. Since streambank erosion measurements are very time consuming, extrapolation of these relations can extend the application and effectiveness of river assessments.

\section{References}

Rosgen (2001) A practical method of computing stream bank erosion rate (Nevada: 7th Federal Interagency Sediment Conference, March 24-29)

Lan, P.T.H. (2017) River morphology assesment from Hoa An to Ghenh Brigde.

\section{Acknowledgement}

This study is funded by the project "Research the forecast of bank erosion, proposing measures to stabilize riverbanks and planning of riverside areas for socioeconomic development in the downstream areas of the Dong Nai river system" of Ministry of Science and Technology, Vietnam in KC08-16-20. 